\title{
Biomedical Applications of Polymers -An Overview
}

Joseph Francis $\mathrm{PJ}^{1 *}$, Arun $\mathrm{KJ}^{2}$, Navas $\mathrm{AA}^{3}$ and Irene Joseph ${ }^{2}$

${ }^{1}$ Department of Biochemistry, Oman Medical College, Oman

${ }^{2}$ Department of physics, Sree Kerala Varma College, India

${ }^{3}$ Department of Internal Medicine, Oman Medical College, Oman

Submission: April 11, 2018; Published: June 11, 2018

*Corresponding author: Joseph Francis PJ, Department of Biochemistry, Oman Medical College, PO Box 391, Postalcode-321, Al Tareef, Sohar, Sultanate of Oman, Oman, Tel: +968-95715139; Fax: +96826843545; Email: josephp@omc.edu.om

\section{Abstract}

Polymers are macromolecules, versatile in structure, constitution and properties. They have wide range of applications in various fields such as biophysics, medicine, electronics, and other branches of science and technology. Among these polymers biomedical polymers are specially mentioned due to their less toxicity in vivo, easy to process and sterilized, better shelf life, light weight, and remarkable properties suited to the applications [1]. This paper explores the various applications of biomedical polymers in the field of medicine.

Keywords: Macromolecules; Biorecognition; Biocatalysis; Bioadhesive drug delivery systems; Smart polymers; Bioseparation; Biocompatibility; Biodegradability

\section{Introduction}

The very first reported synthetic polymer for medical use is poly (methyl methacrylate) (PMMA) by a British ophthalmologist, Sir Nicholas Harold, in 1949 for making intraocular lens [2]. Biostability and biodegradability are the two important parameters to be noticed to select a polymer for its biomedical use. Homo- and copolymers of polyamides, polyesters, polyanhydrides, poly (ortho esters), poly (amido amines), and poly ( $\beta$-amino esters) are the important biomedical polymers which are hydrolytically degradable [3]. These are also called biopolymers and smart polymers which are mainly used in biotechnology and medicine. Their applications basically include biorecognition and biocatalysis, in aqueous solutions [4] which involves very fast and reversible chemical and physical changes.

\section{Mucoadhesive Polymers}

These are used for ophthalmic delivery and buccal delivery of drugs due to their enhancement of body area and their residence time [5]. Polyacrylic acid (PAAc) is used for bioadhesive drug delivery systems. Polymers are essential for controlled drug release in transdermal patches, microspheres, pumps, aerosols, ocular implants, and contraceptive implants. The mechanism of this drug release is of three different ways, one is the diffusion-controlled way, in which the drug is released by solution-diffusion through a polymer. The second way is the erosion-controlled route, in which the drug release is activated by dissolution, disintegration or biodegradation of the polymer
[6]. In the third method the drug release is done by the rate of osmotic absorption of water from the environment and they are called osmotically controlled systems [6].

\section{Smart Polymers and Bioseparation}

Smart polymers are used for drug delivery and used to solve bioseparation problems. They copy biological systems and show flexibility and remarkable potentials in aqueous solutions [5]. Most of the smart polymers have stimulus responsive nature in water. For example, hydrogels are like linear polymers which are 3D structures that swell, do not dissolve in water and it will function in response to the stimulus. They help the process of bio-separation due to the ease of series of volume changes in response to the external stimulus [7]. Changes in $\mathrm{pH}$ or temperature, cause swelling or shrinking of hydrogel beads and can be used to control drug release as diffusion of the drug depends on the physical state [8].

Polymers Used for Vascular Prostheses and Cardiopulmonary Bypass Surgery

Polymers used for vascular prostheses or good blood flow include poly (ethylene terephthalate) fibers, expanded polytetrafluoroethylene foams, segmented porous polyurethanes, and microporous silicone rubber [9]. Polymers are also used to oxygenate blood and should be made sure that they operate without blood damage. Polypropylene has been used in both solid and microporous forms during cardiopulmonary bypass surgery [9]. 
Natural and Synthetic Biodegradable Polymers and Fibers

Both natural and synthetic polymers are used in medical prosthetic applications like heart valves, stents, cartilage scaffolds, joints, making of artificial skin, blood vessels, Urinary catheters, ureteral stents, artificial kidney/Hemodialysis membranes and also in nano systems for drug delivery. Now days as the nano delivery of drugs to the target organs are an ongoing advancement, importance of biodegradable polymers in the field of medicine is sky rocketing. Biodegradability of materials used for nano delivery, both in the treatment and imaging, is important as the accumulation of used materials leads to toxicity. The degraded products define the biocompatibility of a polymer. For example, poly (lactic-co-glycolic acid) (PLGA), poly (glycolic acid) (PGA) and poly(lactic acid) (PLA) have been approved by the US Food and Drug Administration (FDA) for certain medical applications, because their products of degradation are eliminated from the body in the form of carbon dioxide and water [10]. Semipermeable membrane biopolymers (cellulose), with less antigenicity used in artificial kidney for hemodialysis is futuristic with reduced or no use of immunosuppressive drugs.

Extracorporeal membrane oxygenation [ECMO] is one of the major breakthroughs in medicine. ECMO uses hydrophobic, microporous, hollow fiber membranes with pores of less than $1 \mu \mathrm{m}$ diameter for exchange of $\mathrm{CO}_{2}$ and $\mathrm{O}_{2}$ to blood. Life saving ECMO machine allows the blood to "bypass" the heart and lungs. The blood is directed to the ECMO machine like in hemodialysis unit, ECHMO oxygenate the blood artificially and remove the carbon dioxide.

\section{Conclusion}

The applications of polymers in biomedical field are highly significant and more effective. These are safe, less toxic and comparatively simple. The mechanism of the drug delivery and bioseparation are so efficient and reliable. Smart polymers play wide role in various biomedical applications such as oxygenation of blood and also in cardiopulmonary bypass surgery. Their stimulus response nature and sensitivity to the physical conditions are useful in different applications. Their role as suture materials, tissue adhesives, and vascular grafts, materials for cosmetic implants, dental composites, contact and intraocular lenses, etc. The use of polymers in medicine is innumerable.

\section{References}

1. Middleton JC, Tipton AJ (2000) Synthetic biodegradable polymers as orthopedic devices. Biomaterials 21(23): 2335-2346.

2. Damodaran VB, Joslin J, Reynolds MM (2012) Preparing biocompatible materials for non-permanent medical devices. European Pharmaceutical Review 17(5): 71-77.

3. Carmali S, Brocchini S (2014) Polyacetals. Natural and Synthetic Biomedical Polymers 2014: 219-233.

4. Yu I, Galaev, Mattiasson B (2002) Polymers, biotechnology and medical applications.

5. Patil NV (2006) Smart polymers are in the biotech future. Bio Process International.

6. Liechty WB, Kryscio DR, Slaughter BV, Peppas NA (2010) Polymers for drug delivery systems. Annu Rev Chem Biomol Eng 1: 149-173.

7. Galaev I, Mattiasson B (1999) Smart polymers and what they could do in biotechnology and medicine. Trends Biotechnol 17(8): 335-340.

8. Kim YH, Kwon IC, Bae YH, Kim SW (1995) Saccharide effect on the lower critical solution temperature of thermo sensitive polymers. Macromolecules 28(4): 939-944.

9. The Shifting Research Frontiers (1994) Polymer science and engineering.

10. Liu H, Slamovich EB, Webster TJ (2006) Less harmful acidic degradation of poly (lacticco-glycolic acid) bone tissue engineering scaffolds through titania nanoparticle addition. Int J Nanomedicine 1(4): 541-545.
Your next submission with Juniper Publishers will reach you the below assets

- Quality Editorial service

- Swift Peer Review

- Reprints availability

- E-prints Service

- Manuscript Podcast for convenient understanding

- Global attainment for your research

- Manuscript accessibility in different formats

( Pdf, E-pub, Full Text, Audio)

- Unceasing customer service

Track the below URL for one-step submission https://juniperpublishers.com/online-submission.php 